\title{
Eubacterium contortum (Prévot) comb. nov.: Emendation of Description and Designation of the Type Strain
}

\author{
LILLIAN V. HOLDEMAN, ELIZABETH P. CATO, and W. E. C. MOORE
}

Anaerobe Laboratory, Division of Basic Sciences, College of Agriculture, Virginia Polytechnic Institute and State University, Blacksburg, Virginia 24061

A type strain for Catenabacterium contortum Prévot has heretofore not been established. Prévot's strain 113 VI [ATCC (American Type Culture Collection) 25540; VPI (Virginia Polytechnic Institute) 0119], one of the two strains upon which the original description of this organism was based, possesses characteristics which closely agree not only with those given in the original description of $C$. contortum by Prévot, but also with those in the description of this organism as emended by the present authors. This strain is here designated as the type strain. The characteristics of $C$. contortum indicate that this organism properly belongs in the genus Eubacterium Prévot, to which genus it is transferred as Eubacterium contortum (Prévot) comb. nov.

In 1947 Prévot (2) described and named Catenabacterium contortum on the basis of two strains: 113 VI and 148 III. However, neither Prévot nor any other author has designated either of these two strains as the type. The intent of this paper is to establish the type strain for $C$. contortum, to update the description of this organism, and to place it in the proper genus.

\section{MATERIALS AND METHODS}

Bacterial strains. Prévot's strain 113 VI (from gangrenous appendicitis), one of the two strains on which the original description of $C$. contortum was based, and two similar organisms which we isolated from human feces were the only strains available to us that conformed to the original description of $C$. contortum.

Methods. The methods used to characterize the strains used in this study were described previously (1).

\section{RESULTS AND DISCUSSION}

Prévot's original description and our observations are given in Table 1.

Cells occur in contorted chains with each element clearly separated from the next (Fig. 1). Prévot reported no thermoresistance; none of the strains we studied survived heating at $80 \mathrm{C}$ for $10 \mathrm{~min}$. The original description gives the optimal $p \mathrm{H}$ as 7.4 and reports culture longevity to be several years. It describes colonies in deep agar as lenticular.

Growth in peptone broth is poor; glucose broth cultures are turbid followed by the appearance of crumbs and clearing of the broth. We found that the organism does not attack lactate or produce propionate from threonine. It converts pyruvate primarily to acetate, formate, and alcohols. From glucose, Prévot reported it to produce a mixture of propionic, formic, and lactic acids, volatile amines, aldehydes, and alcohols. In our laboratory, silicic acid and gas chromatographic analyses revealed ethanol, propanol (trace), acetic acid ( 1 to $6 \mathrm{meq} / 100 \mathrm{ml}$ ), formic acid $(0.4 \mathrm{meq} / 100$ $\mathrm{ml})$, and a trace of succinic acid and lactic acid ( 0 to $0.3 \mathrm{meq} / 100 \mathrm{ml}$ ). We believe that the chromatographic procedures available to us are more reliable than the Duclaux distillation procedures used by Prévot for identification of the products.

We were unable to detect ammonia, indole, or acetylmethylcarbinol in cultures of the proposed type strain. The direct Nessler's test we use for ammonia is not as sensitive as the distillation procedure used by Prévot. Old meat used in the preparation of media sometimes contains small amounts of indole, and this may have accounted for the traces of indole that Prévot detected.

On the basis of a comparison of the strains 
TABLE 1. Descriptions of Eubacterium contortum (Prévot) comb. nov. and its type strain

\begin{tabular}{|c|c|c|c|}
\hline Characteristic & $\begin{array}{c}\text { Prévot's descrip- } \\
\text { tion }^{a}\end{array}$ & $\begin{array}{c}\text { Emended descrip- } \\
\operatorname{tion}^{b}\left(\%^{+}\right)\end{array}$ & Type strain $c$ \\
\hline Gram-positive rods $\ldots \ldots \ldots \ldots \ldots$ & + & $+(100)$ & + \\
\hline Anaerobic $\ldots \ldots \ldots \ldots \ldots \ldots \ldots$ & + & $+(100)$ & + \\
\hline Motility .............. & - & $-\quad(0)$ & - \\
\hline Endospores $\ldots \ldots \ldots \ldots \ldots \ldots \ldots$ & - & $-\quad(0)$ & - \\
\hline Capsules $\because \ldots \ldots \ldots \ldots \ldots \ldots \ldots$ & - & & \\
\hline Size $\ldots \ldots \ldots \ldots \ldots \ldots \ldots \ldots$ & $0.5-0.6 \times 3-4 \mu \mathrm{m}$ & $0.4-0.9 \times 1.3-7.1 \mu \mathrm{m}$ & $0.4-0.6 \times 1.3-2.3 \mu \mathrm{m}$ \\
\hline Optimum temp (C) $\ldots \ldots \ldots \ldots \ldots \ldots$ & 37 & $37(100)$ & 37 \\
\hline Adonitol $\ldots \ldots \ldots \ldots \ldots \ldots \ldots \ldots$ & & $-(0)$ & - \\
\hline Amygdalin $\ldots \ldots \ldots \ldots \ldots \ldots \ldots$ & & $-(0)$ & - \\
\hline Arabinose $\ldots \ldots \ldots \ldots \ldots \ldots \ldots$ & + & $+(100)$ & + \\
\hline Cellobiose $\ldots \ldots \ldots \ldots \ldots \ldots \ldots \ldots$ & & $+(100)$ & + \\
\hline Dextrin $\ldots \ldots \ldots \ldots \ldots \ldots \ldots \ldots$ & & $\pm(67)$ & - \\
\hline Dulcitol . . . . . . . . . . . . . & & $\pm(67)$ & - \\
\hline Erythritol $\ldots \ldots \ldots \ldots \ldots \ldots \ldots \ldots$ & & $-\quad(0)$ & - \\
\hline Esculin $\ldots \ldots \ldots \ldots \ldots \ldots \ldots \ldots$ & & $\pm(67)$ & - \\
\hline Fructose $\ldots \ldots \ldots \ldots \ldots \ldots \ldots \ldots$ & + & $+(100)$ & + \\
\hline Galactose $\ldots \ldots \ldots \ldots \ldots \ldots \ldots$ & + & $+(100)$ & + \\
\hline Glucose $\ldots \ldots \ldots \ldots \ldots \ldots \ldots$ & + & $+(100)$ & + \\
\hline Glycerol $\ldots \ldots \ldots \ldots \ldots \ldots \ldots$ & & $\pm(33)$ & - \\
\hline Inositol $\ldots \ldots \ldots \ldots \ldots \ldots \ldots$ & & $-(0)$ & - \\
\hline Inulin $\ldots \ldots \ldots \ldots \ldots \ldots \ldots \ldots \ldots$ & & $\pm(67)$ & - \\
\hline Lactose $\ldots \ldots \ldots \ldots \ldots \ldots \ldots$ & & $+(100)$ & + \\
\hline Maltose $\ldots \ldots \ldots \ldots \ldots \ldots \ldots$ & + & $+(100)$ & + \\
\hline Mannitol $\ldots \ldots \ldots \ldots \ldots \ldots \ldots$ & & $-\quad(0)$ & - \\
\hline Mannose $\ldots \ldots \ldots \ldots \ldots \ldots \ldots \ldots$ & & $\pm(67)$ & + \\
\hline Melezitose $\ldots \ldots \ldots \ldots \ldots \ldots \ldots$ & & $-\quad(0)$ & - \\
\hline Melibiose $\ldots \ldots \ldots \ldots \ldots \ldots \ldots$ & & $+(100)$ & + \\
\hline 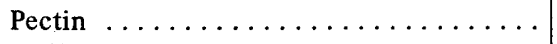 & & $+(100)$ & + \\
\hline Raffinose $\ldots \ldots \ldots \ldots \ldots \ldots \ldots$ & & $+(100)$ & + \\
\hline Rhamnose $\ldots \ldots \ldots \ldots \ldots \ldots \ldots$ & & $+(100)$ & + \\
\hline Ribose $\ldots \ldots \ldots \ldots \ldots \ldots \ldots \ldots \ldots$ & & $+(100)$ & + \\
\hline Salicin $\ldots \ldots \ldots \ldots \ldots \ldots \ldots \ldots$ & & $+(100)$ & + \\
\hline Sorbitol $\ldots \ldots \ldots \ldots \ldots \ldots \ldots$ & & $-\quad(0)$ & - \\
\hline Sorbose $\ldots \ldots \ldots \ldots \ldots \ldots \ldots \ldots$ & & $-\quad(0)$ & - \\
\hline 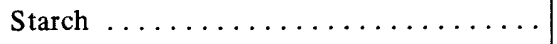 & & $+(100)$ & + \\
\hline Sucrose $\ldots \ldots \ldots \ldots \ldots \ldots \ldots$ & + & $+(100)$ & + \\
\hline Xylose $\ldots \ldots \ldots \ldots \ldots \ldots \ldots \ldots$ & + & $+(100)$ & + \\
\hline 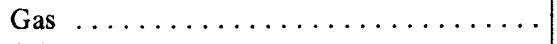 & + & $+(100)$ & + \\
\hline Odor $\ldots \ldots \ldots \ldots \ldots \ldots \ldots \ldots$ & - & $-\quad(0)$ & - \\
\hline 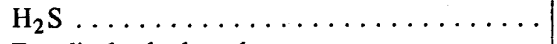 & - & $-\quad(0)$ & - \\
\hline Esculin hydrolyzed $\ldots \ldots \ldots \ldots \ldots$ & & $+(100)$ & + \\
\hline Starch hydrolyzed .............. & & $-\quad(0)$ & - \\
\hline Hippurate hydrolyzed $\ldots \ldots \ldots \ldots \ldots$ & & $(0)$ & - \\
\hline Gelatin liquefied $\ldots \ldots \ldots \ldots \ldots$ & - & $-\quad(0)$ & - \\
\hline Milk coagulated $\ldots \ldots \ldots \ldots \ldots \ldots$ & - & $\pm(67)$ & - \\
\hline Meat digested $\ldots \ldots \ldots \ldots \ldots \ldots$ & & $-\quad(0)$ & - \\
\hline Catalase $\ldots \ldots \ldots \ldots \ldots \ldots \ldots \ldots \ldots \ldots$ & & $-\quad(0)$ & - \\
\hline Neutral red reduced $\ldots \ldots \ldots \ldots \ldots \ldots$ & + & $+(100)$ & + \\
\hline Nitrate reduced $\ldots \ldots \ldots \ldots \ldots \ldots$ & - & $-\quad(0)$ & - \\
\hline 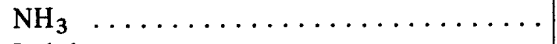 & + & $\pm(33)$ & - \\
\hline Indole $\ldots \ldots \ldots \ldots \ldots \ldots \ldots \ldots$ & trace & $-\quad(0)$ & - \\
\hline Acetylmethylcarbinol $\ldots \ldots \ldots \ldots \ldots$ & + & $\pm(50)$ & - \\
\hline
\end{tabular}

${ }^{a}$ See reference 2 .

$b$ Emended species description by Holdeman, Cato, and Moore on the basis of 3 strains.

${ }^{c}$ ATCC 25540; Prévot 113 VI; VPI (Virginia Poly technic Institute) 0119. 


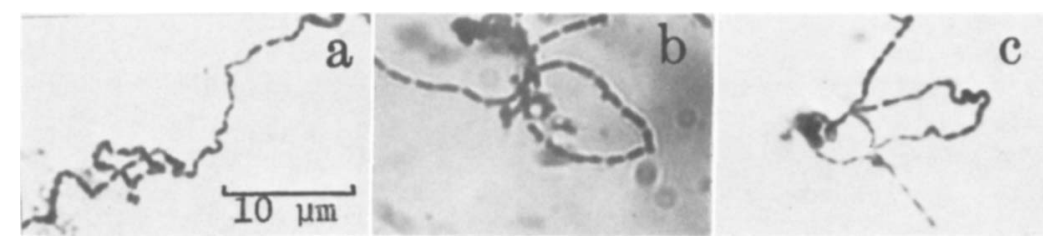

FIG. 1. Cellular morphology of Eubacterium contortum ATCC 25540: Gram stain of 24-hr broth cultures. a, peptone-yeast extract broth; $b$, chopped meat medium; $c$, glucose broth.

recently isolated from human feces with Prévot's strain 113 VI, it appears that members of this species may or may not produce acid from dextrin, dulcitol, esculin, glycerol, inulin, and mannose.

Milk is coagulated by strains which produce strong acid in lactose. Prévot's strain $113 \mathrm{VI}$

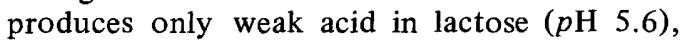
whereas the two recent isolates produce strong

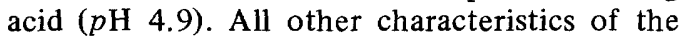
three available strains are identical.

Prévot reported that strain 148 III was not pathogenic for guinea pigs. One $\mathrm{ml}$ of strain 113 VI injected intramuscularly into a guinea pig produced a fatal gelatinous edema in $24 \mathrm{hr}$. The strain lost pathogenicity in subsequent cultures. It produced no toxin or hemolysin.

We propose that this species be placed in the genus Eubacterium because, among authentic cultures of several species of Eubacterium and Catenabacterium, there was an overlapping of the lengths of filaments and chains which were produced. This overlap prevented accurate differentiation of the genera. The name of this organism, therefore, is Eubacterium contortum (Prévot) comb. nov.

Characteristics which qualify E. contortum as a member of Eubacterium. This species is a member of Eubacterium because it is a grampositive, obligately anaerobic, nonsporeforming rod which does not produce propionic acid as a major acid product (as does Propionibacterium); lactic as a sole major acid product (as does Lactobacillus); large amounts of succinic (in the presence of $\mathrm{CO}_{2}$ ) and lactic acids, sometimes with acetic and formic acids (as does Actinomyces), or acetic and lactic (acetic $\geq$ lactic), with or without formic, as sole major acid products (as does Bifidobacterium).

Characteristics which constitute the basic concept of the species E. contortum and differentiate it from other species in the genus. Although there are organisms with a morphology similar to that of $E$. contortum that might be confused with this species, the pattern of substrates attacked, the absence of complete gelatin liquefaction, the production of major amounts of acetic acid $(1.2$ to $6.5 \mathrm{meq} / 100 \mathrm{ml})$ and moderate amounts of formic acid ( 0.4 meq $/ 100 \mathrm{ml}$ ), with or without traces of lactic and succinic acids, and the absence of indole and nitrite production distinguish this species from other members of the genus.

Designation of the type strain of $E$. contortum. Strain 113 VI (ATCC 25540; VPI 0119) still exhibits characteristics that generally agree with those cited in the original description of $C$. contortum by Prévot (see Table 1). There are few differences from the original description, and most can be readily explained. We believe this strain represents the organism originally described by Prévot (2). Since he did not designate a type strain, we wish to designate strain $113 \mathrm{VI}$ as the type of $E$. contortum (Prévot) comb. nov.

\section{ACKNOWLEDGMENTS}

We thank Gertrude M. Surface and Mary $P$. Harvey for their assistance in this work.

This investigation was supported by Public Health Service grant GM 14604 from the National Institute of General Medical Sciences.

\section{LITERATURE CITED}

1. Anaerobe Laboratory. 1970. Outline of clinical methods in anaerobic bacteriology, 2nd rev., p. 1-107. Virginia Polytechnic Institute and State University, Blacksburg, Va.

2. Prévot, A.-R. 1947. Etude de quelques bactéries anaérobies nouvelles ou mal connues. Ann. Inst. Pasteur (Paris) 73:409-418. 